\title{
REVIEW
}

\section{Perspectives on future Alzheimer therapies: amyloid- $\beta$ protofibrils - a new target for immunotherapy with BAN2401 in Alzheimer's disease}

\author{
Lars Lannfelt ${ }^{1,2^{*}}$, Christer Möller ${ }^{2}$, Hans Basun ${ }^{1,2}$, Gunilla Osswald², Dag Sehlin ${ }^{1}$, Andrew Satlin ${ }^{3}$,
}

Veronika Logovinsky ${ }^{3}$ and Pär Gellerfors ${ }^{2}$

\begin{abstract}
The symptomatic drugs currently on the market for Alzheimer's disease (AD) have no effect on disease progression, and this creates a large unmet medical need. The type of drug that has developed most rapidly in the last decade is immunotherapy: vaccines and, especially, passive vaccination with monoclonal antibodies. Antibodies are attractive drugs as they can be made highly specific for their target and often with few side effects. Data from recent clinical AD trials indicate that a treatment effect by immunotherapy is possible, providing hope for a new generation of drugs. The first anti-amyloid-beta (anti-A $A$ ) vaccine developed by Elan, AN1792, was halted in phase 2 because of aseptic meningoencephalitis. However, in a follow-up study, patients with antibody response to the vaccine demonstrated reduced cognitive decline, supporting the hypothesis that $A \beta$ immunotherapy may have clinically relevant effects. Bapineuzumab (Elan/Pfizer Inc/Johnson \& Johnson), a monoclonal antibody targeting fibrillar $A \beta$, was stopped because the desired clinical effect was not seen. Solanezumab (Eli Lilly and Company) was developed to target soluble, monomeric A $\beta$. In two phase 3 studies, Solanezumab did not meet primary endpoints. When data from the two studies were pooled, a positive pattern emerged, revealing a significant slowing of cognitive decline in the subgroup of mild AD. The Arctic mutation has been shown to specifically increase the formation of soluble $A \beta$ protofibrils, an $A \beta$ species shown to be toxic to neurons and likely to be present in all cases of AD. A monoclonal antibody, mAb158, was developed to target $A \beta$ protofibrils with high selectivity. It has at least a 1,000-fold higher selectivity for protofibrils as compared with monomers of $A \beta$, thus targeting the toxic species of the peptide. A humanized version of mAb158, BAN2401, has now entered a clinical phase 2b trial in a collaboration between BioArctic Neuroscience and Eisai without the safety concerns seen in previous phase 1 and $2 a$ trials. Experiences from the field indicate the importance of initiating treatment early in the course of the disease and of enriching the trial population by improving the diagnostic accuracy. BAN2401 is a promising candidate for A immunotherapy in early AD. Other encouraging efforts in immunotherapy as well as in the small-molecule field offer hope for new innovative therapies for $A D$ in the future.
\end{abstract}

\section{Introduction}

Immunotherapy has emerged as a promising treatment option for Alzheimer's disease (AD), the most common form of dementia [1]. The lack of an effective treatment is an increasing socioeconomic threat. Although many challenges remain, data from drug programs within the immunotherapy area indicate that treatment effects are

\footnotetext{
* Correspondence: Lars.Lannfelt@pubcare.uu.se

'Department of Public Health/Geriatrics, Uppsala University, Dag Hammarskölds väg 14 B, 75185 Uppsala, Sweden

${ }^{2}$ BioArctic Neuroscience AB, Warfvinges väg 35, 11251 Stockholm, Sweden Full list of author information is available at the end of the article
}

possible, providing hope for a new generation of therapies in the future.

The underlying pathogenic mechanism for the development of AD is subject to ongoing discussions. According to the amyloid hypothesis, the amyloid-beta $(A \beta)$ peptide, which is the main constituent of extracellular plaques found in $\mathrm{AD}$ brains [2], initiates the disease process and therefore is an attractive target for intervention $[3,4]$. This hypothesis has been supported by the findings of several mutations in the $A \beta$ region of the amyloid-beta precursor protein (AßPP) as well as in 
other genes in families with autosomal dominant, earlyonset $\mathrm{AD}$ [5-9]. The mutations have been shown to increase the production of $\mathrm{A} \beta$ in vitro as well as in vivo (reviewed in $[3,10])$. The Arctic mutation (ABPP E693G) points to large soluble $A \beta$ oligomers (that is, protofibrils) to be toxic and driving the disease process. We found that the Arctic $A \beta$ peptide had a propensity to form large soluble $\mathrm{A} \beta$ protofibrils [8], and later studies on $\mathrm{AD}$ cases with the Arctic mutation indeed showed that they are negative for fibrillized amyloid, as measured by binding of Pittsburg compound B ( $\left.{ }^{11} \mathrm{C}-\mathrm{PIB}\right)$ to brain amyloid with positron emission tomography (PET) [11]. However, in the most prevalent form of the disease, lateonset sporadic $\mathrm{AD}$, decreased $\mathrm{A} \beta$ clearance rather than increased production is initiating the disease process [12]. A recent finding of a protective mutation in the $A \beta P P$ gene $(\mathrm{A} 673 \mathrm{~T})$ resulted in reduced $\beta$-secretase cleavage of $\mathrm{A} \beta \mathrm{PP}$ as well as a lowered risk of developing sporadic $\mathrm{AD}$ and slowing of the rate of cognitive decline in an older population [13], further strengthening the amyloid hypothesis.

The lack of effect on disease progression in $\mathrm{AD}$ by the symptomatic drugs currently on the market creates a large unmet medical need. Many new candidate drugs are targeting the production, aggregation, or clearance of $A \beta$ such as $\gamma$-secretase inhibitors $[14,15]$ and $\beta$-secretase inhibitors [16-18]. Other interesting approaches are small molecules targeting pyroglutamated toxic $A \beta$ peptides [19] or aggregated $A \beta[20,21]$.

\section{Amyloid-beta immunotherapy}

Biopharmaceuticals constitute the class of drugs that has developed most rapidly during the last decade. These drugs include monoclonal antibodies and molecules stimulating the patient's own immune system. A number of immunotherapy programs for $\mathrm{AD}$ aimed at lowering the amount of $A \beta$ in brain have evolved. Immunotherapy targeting $A \beta$ has emerged as an attractive approach for disease intervention in $\mathrm{AD}$, as $\mathrm{A} \beta$ immunotherapy in general confers a lower risk of side effects in a vulnerable patient population during long-term treatment as compared with small-molecule anti-A $\beta$ therapy. However, $A \beta$ immunotherapy is not without side effects, as has been seen in the AN1792 trial [22] with meningoencephalitis in some patients and vasogenic edema or microhemorrhages (or both) in the Bapineuzumab trial [23]. One advantage with antibodies is that they can be made with high specificity for its target, and antibodies usually have a more favorable safety profile than small molecules. Importantly, results from some late-phase anti-A $\beta$ immunotherapy studies indicate that positive effects in the clinic are possible, which is encouraging for continued research.
The two approaches most used in immunotherapy are active and passive immunization. Active immunization includes administration of an antigen to increase the immune response and generate antibodies in the recipient. The advantage of this approach is that it could give a long-term response, requiring fewer administrations of the drug, and also the cost of goods is low. A disadvantage could be that the polyclonal response has a varying amount and specificity of the antibodies generated, in some cases not generating meaningful titers. Especially in an older population such as the late-onset AD group, age-related attenuation of the immune system will affect the efficacy of active immunotherapy. The specificity of the generated antibodies can be difficult to predict, and adverse reactions may be persistent and difficult to treat. In passive immunization, externally generated antibodies are injected into the recipient. These antibodies can be donor-derived human polyclonal antibodies or can be humanized monoclonal antibodies. The advantage of the latter approach is that it allows precise targeting of epitopes. The disadvantage is that it requires frequent intravenous (i.v.) or subcutaneous administrations. For the future, long-term prevention of $\mathrm{AD}$ seems more feasible with an active vaccine; however, this requires very adequate biomarkers to know how to select the patients.

\section{Previous data from clinical amyloid-beta immuno- therapy programs}

The development of the vaccine AN1792 by Elan (Dublin, Ireland) started when it was observed that immunization of $A \beta P P$ transgenic mice with fibrillar $A \beta$ in combination with an adjuvant led to formation of anti-A $\beta$ antibodies and clearance of existing amyloid deposits and also prevention of the formation of new deposits. AN1792 was halted in phase 2 because of aseptic meningoencephalitis in $6 \%$ of the treated patients [22]. The clinical outcomes were not improved in the active group as compared with the placebo group. However, postmortem examinations of brains from several study participants receiving the drug demonstrated fewer amyloid deposits than would be expected in patients at such a late stage of the disease, indicating that AN1792 had reached its target [24]. In a follow-up study performed 4.6 years after the immunizations were conducted in the phase 2 study, previously identified antibody responders were compared with placebo-treated patients [25]. The antibody responders maintained a low antibody titer and demonstrated significantly reduced cognitive decline compared with placebo-treated patients, supporting the hypothesis that $A \beta$ immunotherapy may have long-term effects.

Passive i.v. immunization in the program for Bapineuzumab (Elan/Pfizer Inc., New York, NY, USA/Johnson \& Johnson, New Brunswick, NJ, USA), a monoclonal 
antibody targeting fibrillar $A \beta$ and directed against $A \beta 1-5$, was stopped in 2012 after failing to reach the clinical endpoint in phase 3. Interestingly, Bapineuzumab treatment lead to a small but significant reduction of total tau as well as phospho-tau in cerebrospinal fluid (CSF) [26], indicating a reduction of neural loss. The levels of $A \beta$ in CSF did not differ between Bapineuzumab- or placebo-treated patients. In a separate study in 28 patients with $\mathrm{AD}$, the amyloid load was found to be reduced in the brains of patients treated with Bapineuzumab as compared with placebo, as measured by binding of ${ }^{11} \mathrm{C}$-PIB to brain amyloid with PET [27]. Bapineuzumab treatment was associated with vasogenic edema called amyloid-related imaging abnormalities with parenchymal edema as well as intracerebral microhemorrhages. This could be the result of antibodies binding and dissolving aggregated $A \beta$ in brain tissue as well as in blood vessel walls, where a local reaction may lead to impairment of the blood-brain barrier. The adverse event profile resulted in a lowering of the dose, and the desired clinical effect was not achieved. This led to the termination of the i.v. program. One possible explanation for these observations is that the drug was given too late in the disease progression or that, owing to misdiagnosis, the trial population was not sufficiently enriched. Alternatively, the dose was too low because of safety concerns.

Solanezumab (Eli Lilly and Company, Indianapolis, IN, USA) was developed to target the mid-region of soluble, monomeric $A \beta$. In a phase 2 study of Solanezumab in mild to moderate $\mathrm{AD}$, a dose-dependent increase in CSF $A \beta_{42}$ was observed. No effect was found on CSF tau, amyloid PET, hippocampal volume, or Alzheimer Disease Assessment Scale-cognitive subscale (ADASCog) [28]. In two phase 3 studies, Solanezumab failed to meet primary clinical endpoints [29]. However, when data from the two studies later were pooled, a positive pattern emerged, revealing a significant slowing of cognitive decline in the subgroup of mild $\mathrm{AD}$. In addition, a significant improvement was seen in functional scores.

\section{Ongoing clinical programs: active amyloid-beta immunotherapy}

Several active immunotherapy programs have reached clinical phase, as listed in Table 1. Affitope AD02 is designed to induce antibody production without $\mathrm{T}$-cell activation, as $\mathrm{T}$ cells were seen in patients with meningoencephalitis in the AN1792 trial. It has been reported to meet primary safety and tolerability endpoints in phase 1. CAD106 targets $A \beta$ oligomers and has met the primary safety and tolerability endpoints in a third phase 2 study, after multiple subcutaneous injections in patients with mild AD [30]. Additional active immunotherapy programs in early clinical development are listed in Table 1.

\section{Ongoing clinical programs: passive amyloid-beta immunotherapy}

Likely owing to the challenges with active immunization described above, passive $A \beta$ immunization programs are currently more numerous (Table 2). Eli Lilly and Company has announced that a new phase 3 study in patients with mild AD will be performed with Solanezumab, and the antibody has also been selected for evaluation in prodromal familial $\mathrm{AD}$ in the Dominantly Inherited Alzheimer Network (DIAN) Trial and the Anti-Amyloid Treatment in Alzheimer's Disease Prevention Trial (A4), as described below. Gantenerumab (Roche, Basel, Switzerland), also in the DIAN trial, is intended for use in prodromal $\mathrm{AD}$ and is currently in phase $2 / 3$ of clinical development, and it targets a combination of the $\mathrm{N}$-terminal and mid-regions of $\mathrm{A} \beta$. BAN2401 (Eisai, Tokyo, Japan/BioArctic Neuroscience, Stockholm, Sweden) selectively targets soluble A $\beta$ protofibrils and is currently in phase $2 b$, having shown a favorable safety profile in earlier studies. Crenezumab (Genentech, South San Francisco, CA, USA/Roche) targets oligomeric and fibrillar forms of $A \beta$ in mild to moderate $\mathrm{AD}$ and is in phase 2 of clinical development as well as in the Alzheimer's Prevention Initiative (API), as described below. Additional passive anti-A $\beta$ immunotherapy

Table 1 Ongoing and terminated active amyloid-beta immunotherapy clinical programs in Alzheimer's disease

\begin{tabular}{lccc}
\hline Name & Company & Phase & Antigen \\
\hline Affitope AD02 & Affiris/GlaxoSmithKline & 2 & $A \beta_{1-6}$ \\
CAD106 & Novartis & 2 & $A \beta_{1-6}$ \\
Vanutide cridificar & Elan/Johnson \& Johnson/Pfizer Inc. & 2 & $A \beta_{1-6}$ \\
ACI24 & AC Immune/Bayer Healthcare Pharmaceuticals & $1 / 2$ & Not published \\
V950 & Merck \& Co. & 1 & Pyroglutamate modified AB \\
Affitope AD03 & Affiris/GlaxoSmithKline & 1 & $A \beta_{1-14}$ \\
UB311 & United Biomedical & A & $A \beta_{1-42}$ \\
AN1792 & Elan & Terminated &
\end{tabular}

$\mathrm{A} \beta$, amyloid-beta. 
Table 2 Ongoing and terminated passive immunotherapy clinical programs in Alzheimer's disease

\begin{tabular}{|c|c|c|c|c|c|}
\hline Name & Company & Phase & Trial population & Binding domain & Target \\
\hline Solanezumab & Eli Lilly and Company & 3 & $\begin{array}{l}\text { Prodromal and } \\
\text { mild } A D\end{array}$ & $A \beta_{16-23}$ & Soluble $A B$ \\
\hline Gantenerumab & Roche & $2 / 3$ & $\begin{array}{l}\text { Prodromal and } \\
\text { mild AD }\end{array}$ & $\begin{array}{l}\text { Combined A } \beta \mathrm{N} \text {-terminal and } \\
\text { mid domain, conformational }\end{array}$ & Aggregated $A \beta$ \\
\hline BAN2401 & $\begin{array}{c}\text { Eisai/ BioArctic } \\
\text { Neuroscience/Eisai }\end{array}$ & $2 b$ & $\begin{array}{l}\mathrm{MCl} \text { due to } A D \text { or } \\
\text { mild } A D\end{array}$ & $\mathrm{~N}$-terminal, conformational & Soluble $A \beta$ protofibrils \\
\hline Crenezumab & Genentech/Roche & 2 & $\begin{array}{l}\text { Prodromal and } \\
\text { mild/moderate } A D\end{array}$ & $A \beta 12-23$ & $\begin{array}{l}\text { Soluble oligomeric/ } \\
\text { fibrillar } A \beta \text { and plaque }\end{array}$ \\
\hline Bapineuzumab & $\begin{array}{l}\text { Elan/ Pfizer Inc./ } \\
\text { Johnson \& Johnson }\end{array}$ & $\begin{array}{c}\text { Intravenous and } \\
\text { subcutaneous programs } \\
\text { terminated }\end{array}$ & Mild/moderate AD & $A \beta_{1-5}$ & $\begin{array}{c}\text { Soluble and } \\
\text { aggregated } A \beta\end{array}$ \\
\hline BlIB037 & $\begin{array}{l}\text { Biogen Idec/ } \\
\text { Neuroimmune } \\
\text { Therapeutics }\end{array}$ & 1 & $\begin{array}{l}\mathrm{MCl} \text { due to } A D \text { or } \\
\text { mild } A D\end{array}$ & Conformational $A \beta$ & Fibrillar $A \beta$ \\
\hline AAB003 & $\begin{array}{l}\text { Elan/Pfizer Inc./ } \\
\text { Janssen }\end{array}$ & 1 & Mild/moderate AD & $A \beta_{1-6}$ & $\begin{array}{c}\text { Soluble and } \\
\text { aggregated } A \beta\end{array}$ \\
\hline SAR228810 & Sanofi & 1 & Mild/moderate AD & Not published & $\begin{array}{c}\text { Soluble oligomeric/ } \\
\text { protofibrillar } A \beta\end{array}$ \\
\hline ABP102 & Abiogen Pharma & 1 & $A D$ & Catalytic antibody cleaving $A \beta$ & Aggregated $A \beta$ \\
\hline Ponezumab ${ }^{a}$ & Pfizer Inc. & 1 & Mild/moderate AD & $A \beta_{33-40}$ & $\begin{array}{c}\text { Soluble and } \\
\text { aggregated } A \beta\end{array}$ \\
\hline
\end{tabular}

an phase 2 in congophilic amyloid angiopathy. $A \beta$, amyloid-beta; $A D$, Alzheimer's disease; $M C l$, mild cognitive impairment.

programs in early clinical development are listed in Table 2 .

\section{Problems with current trials}

The recent setbacks with many anti-amyloid small molecules and immunotherapies do not necessarily mean that $\mathrm{A} \beta$ is the wrong target for $\mathrm{AD}$ treatment. In the recent late-phase failures, a subset of the trial population with mild to moderate AD is likely misdiagnosed, as the clinical AD diagnosis is difficult to make. It is also possible that the severity of disease in the trial population did not allow for clinical improvement (that is, the treatment was given too late in the disease progression) or that instruments for measurement of effect were not sensitive enough. The poor clinical outcome could also be caused by low dosing due to safety findings that limited the dose ranges.

Even though $\mathrm{A} \beta$ has remained the focus of $\mathrm{AD}$ research since the peptide was found to be the main constituent of senile plaques, it also has been shown that the amyloid plaque density in brain in fact does not correlate with the severity of dementia [31-34]. However, during the 1990s, several research groups showed that neuronal injury was caused by soluble aggregated $A \beta$ species $[35,36]$. Soluble $A \beta$ is thus an interesting target for $\mathrm{AD}$ disease-modifying treatment. However, as soluble $\mathrm{A} \beta$ can be anything from monomers to large protofibrils, correct target identification requires a profound understanding of $\mathrm{A} \beta$ toxicity.

\section{Improving amyloid-beta immunotherapy - protofibrils: a new drug target}

During the aggregation of monomeric $A \beta$ to insoluble fibrils, an intermediate species that is called protofibrils and that was first described by Walsh and colleagues [37] in 1997 is formed. Using synthetic A $\beta$ peptide, protofibrils have been defined as large $(>100 \mathrm{kDa})$ soluble oligomeric species appearing as a peak in the void volume of a size exclusion chromatography system with a Sephadex G75 column [8,37]. These protofibrils have been shown to induce electrophysiological changes and cause neurotoxicity in rat cortical neurons [38] and inhibit long-term potentiation in mouse hippocampus [39]. $A \beta_{42}$ protofibrils have been shown to induce an inflammatory process through microglial activation in vitro, an effect not seen by insoluble fibrils [40].

The sizes and assembly states of the soluble protofibrils have been investigated, and several oligomers of various sizes have been identified in human brain and in brain from $A \beta P P$ transgenic mice [41-44]. One of the $\mathrm{A} \beta \mathrm{PP}$ mutations causing early-onset familial $\mathrm{AD}$, the Arctic mutation (ABPP E693G), has been shown to specifically increase the rate of formation of protofibrils $[8,45,46]$. Furthermore, the mutation has been shown to facilitate early intraneuronal $A \beta$ aggregation and protofibril formation, followed by plaque formation in tgArcSwe mice $[47,48]$. Cognitive deficits were shown to occur concomitantly with the formation of intracellular $\mathrm{A} \beta$ deposits but before plaque formation in the transgenic mice [48]. The levels of protofibrils in brain, but 
not the levels of total $A \beta$, correlated with spatial learning, adding further evidence to the theory that soluble protofibrils are the toxic species [49]. The pool of toxic $\mathrm{A} \beta$ species was shown to consist of molecules in the size range of 80 to $500 \mathrm{kDa}$ [44]. The toxic species were detected by $\mathrm{mAb158}$, a protofibril-selective antibody with low binding to monomers and aggregated insoluble $A \beta$. mAb158 was isolated by using an inhibition enzymelinked immunosorbent assay in which the antibody and the antigen reacted in solution and in which the selectivity for protofibrils could be detected. In immunohistochemistry, mAb158 detects $A \beta$ in plaques and in the vasculature of $A D$ brains because of the massive amount of $A \beta$ in these structures [43].

In light of the findings described above, $A \beta$ protofibrils are interesting as targets for AD immunotherapy. Transgenic mice carrying both the Swedish and the Arctic mutation were treated with mAb158. mAb158 did not affect the levels of insoluble $A \beta$ in the brains of plaquebearing mice, whereas it prevented plaque formation if treatment began before the appearance of senile plaques. In both cases, soluble $A \beta$ protofibril levels were diminished [50], showing that mAb158 can selectively reduce protofibrils in vivo. A humanized version of mAb158BAN2401, developed by BioArctic Neuroscience-has binding characteristics essentially indistinguishable from those of mAb158 with at least a 1,000-fold higher selectivity for protofibrils compared with monomers (manuscript in preparation) and 10 to 15 times less binding to fibrils as compared with protofibrils [44]. BAN2401 has now entered a clinical phase $2 \mathrm{~b}$ trial, as described below.

\section{Going forward - how can the outcomes of clinical trials be improved?}

Many of the anti-A $\beta$ agents tested in humans have been proven to reach their target as shown by measurement of biomarkers. Yet none of them has been able to show convincing and significant clinical improvement. Lessons learned from Bapineuzumab, in which clinical improvement was not seen despite demonstrated target engagement, raise questions regarding target relevance, heterogeneity of the patient population, and timing of drug administration with disease progression. Furthermore, it is possible that the effect markers were not sensitive enough and the exposure was too low because of limitations by the safety profile.

\section{Defining the optimal trial population}

The patients included in clinical trials have traditionally been diagnosed as mild to moderate AD. Targeting $\mathrm{A} \beta$ even at this stage of the disease might be too late. Several studies have suggested that the levels of soluble $A \beta$ are increased very early in disease progression and even precede the clinical symptoms [51]. The ideal target population for disease-modifying treatments, such as immunotherapy, could therefore be early $\mathrm{AD}$ (that is, mild cognitive impairment (MCI) due to $\mathrm{AD}$ and mild $\mathrm{AD}$ ). Currently, there are no diagnostic biomarkers that are sensitive and specific enough to detect these early patients with sufficient diagnostic accuracy [52]. Only approximately $60 \%$ of patients with memory deficits or MCI have actually converted to AD after 10 years, and the annual conversion rate was 5\% to $10 \%$ [53]. The high number of patients necessary and long study duration needed for performing clinical trials in this population would therefore be unrealistic. Similarly, results from the Bapineuzumab trials suggest that as much as $30 \%$ of the patients enrolled in studies did not have an AD diagnosis [54]. The diagnostic accuracy can be improved by scanning enrolled subjects for brain amyloid by PET [55] and excluding subjects who do not fulfill the criteria for amyloid load in the brain. This is being done in the ongoing phase $2 \mathrm{~b}$ study with BAN2401 (Eisai/BioArctic Neuroscience) and phase 1 study with BIIB037 (Biogen Idec, Weston, MA, USA). Amyloid PET is also a potential marker of disease progression, which is being evaluated in several trials. The measurement of CSF biomarkers such as $A \beta_{42}$ and tau is another aid in the refinement of the clinical diagnosis [52], and they are being explored as markers of disease progression in several trials. By refining the patient population, treatment effects are more likely to be detected and thereby smaller sample sizes can be used. To shed more light on the preclinical events in $\mathrm{AD}$ and to obtain further regulatory support for the validity of biomarkers for both diagnosis and disease progression, three prospective longitudinal investigations are now under way: the A4 trial, API trial, and the DIAN trial. The API and DIAN trials are performed in families with autosomal dominant inherited mutations. In addition to validating the preclinical phase of $\mathrm{AD}$ and potential biomarkers, potential diseasemodifying drug candidates will be included in the programs: Crenezumab in the API program, Gantenerumab in the DIAN program, and Solanezumab in the DIAN and A4 programs.

\section{Improving the cognitive measurements}

The lack of correlation between markers of target engagement and clinical outcome measures is still an unsolved issue in $\mathrm{AD}$ trials, which mirrors the knowledge gap of the disease pathogenesis. Disease progression is traditionally monitored by a combination of techniques measuring physical features such as brain atrophy (volumetric magnetic resonance imaging) and neuronal loss or dysfunction (fluorodeoxyglucose PET and functional magnetic resonance imaging). Stable and sensitive instruments to measure subtle cognitive changes in $\mathrm{MCI}$ due to $\mathrm{AD}$ as well as in early $\mathrm{AD}$ are not yet in place. 
The methods used for cognitive outcome measures which are approved as effect markers by regulatory agencies are often not sensitive enough for patients with early AD. Eisai has recently developed a new, more sensitive cognitive composite scale -Alzheimer Disease Composite Score [56,57], derived from ADAS-cog, Mini-Mental State Exam, and Clinical Dementia RatingSum of Boxes - and this is used in the ongoing phase $2 \mathrm{~b}$ study with BAN2401.

\section{Improving biomarkers}

In terms of biomarkers, there is currently a lack of understanding of the direction and magnitude of change needed to demonstrate a clinical effect $[51,58]$. Protofibrils/oligomers in CSF are interesting potential AD biomarkers. Currently, CSF tau and $\mathrm{A} \beta_{1-42}$ as well as amyloid PET are used predominantly as an aid for the diagnosis of $\mathrm{AD}$ and only as exploratory markers of disease progression. Many new biomarkers are currently being investigated, providing hope for new biomarkers and predictors of conversion to dementia in the near future.

\section{Finding the right dose and exposure}

Setting the right dose in clinical immunotherapy trials is difficult. The long half-life of the antibodies, in combination with the lack of sensitive and stable effect markers, makes dosing challenging. In the ongoing BAN2401 trial, Eisai and BioArctic Neuroscience have chosen an adaptive Bayesian design [59]. This way, the key endpoint in the study is continuously monitored in a blinded manner, and the number of patients in the different treatment arms can be adjusted to optimize the size and duration of the study. The design contains six treatment arms in combination with several planned interim analyses, enabling greater allocation of patients to the treatment arms that appear to be showing the greatest efficacy. In this way, the clinical trial design is optimized for finding the right dose regimen faster.

\section{A beneficial safety profile}

Bapineuzumab and several other early $A \beta$ immunotherapy programs have encountered safety issues causing the programs to terminate. Triggering the immune system can cause undesired effects. A beneficial safety profile allowing efficient dose levels without undesired side effects is pivotal for success. Many lessons have been learned from failed or terminated immunotherapy programs, and the safety profiles of $A \beta$ immunotherapy drugs are continuously improving. BAN2401 is in early clinical development, and so far no safety concerns have been raised.

\section{Conclusions - BAN2401 in clinical development}

$A \beta$ immunotherapy has gained a lot of attention and emerges as one of the most attractive approaches for disease intervention in $\mathrm{AD} . \mathrm{A} \beta$ neurotoxicity has been shown to be caused by soluble protofibrils rather than insoluble fibrils, and this highlights protofibrils as targets for immunotherapy. Preclinical and clinical data on mAb158/BAN2401 suggest that the antibody targets an $A \beta$ species found to be toxic in a clinical setting as well as in preclinical experiments. Results from previous immunotherapy trials have indicated the importance of targeting early $\mathrm{AD}$, and therefore amyloid PET is used in the ongoing BAN2401 phase 2b trial to identify an early patient population. In the same study, a novel sensitive clinical composite score is being used to monitor disease progression and drug effects. An adaptive study design will allow an optimized number of patients and dose arms in the study. When progressing a chronic treatment into a vulnerable patient population, safety and convenience will be key for a successful treatment. BAN2401 is a promising candidate for $A \beta$ immunotherapy in early $\mathrm{AD}$, according to preclinical and clinical data. Other encouraging efforts in immunotherapy as well as in the small-molecule field offer hope for new innovative therapies for $\mathrm{AD}$ in the future.

Note: This article is part of a series on Immunotherapy in Alzheimer's disease, edited by Philip Scheltens. Other articles in this series can be found at http://alzres.com/series/immunotherapy.

\section{Abbreviations \\ ${ }^{11}$ C-PIB: Pittsburg compound B; A4: Anti-amyloid treatment in alzheimer's disease prevention trial; AD: Alzheimer's disease; ADAS-Cog: Alzheimer disease assessment scale-cognitive subscale; API: Alzheimer's prevention initiative; A $\beta$ : amyloid-beta; A $\beta P P$ : Amyloid-beta precursor protein; CSF: Cerebrospinal fluid; DIAN: Dominantly inherited alzheimer network; i. v.: intravenous; MCl: Mild cognitive impairment; PET: Positron emission tomography.}

\section{Competing interests}

$\mathrm{LL}$ and $\mathrm{PG}$ are founders of BioArctic Neuroscience. $\mathrm{GO}$ is chief executive officer, CM is chief security officer, and HB is chief medical officer. AS is head of clinical development for neuroscience and general medicine at Eisai. VL is the project leader for the BAN2401 program at Eisai. DS declares that he has no competing interests.

\section{Acknowledgments}

The authors thank BAN2401 project teams at BioArctic Neuroscience and at Eisai and Johanna Fälting, Stina Tucker, Karin Tegerstedt, and Hanna Laudon for helpful comments on the manuscript.

\section{Author details}

'Department of Public Health/Geriatrics, Uppsala University, Dag Hammarskölds väg 14 B, 75185 Uppsala, Sweden. ${ }^{2}$ BioArctic Neuroscience AB, Warfvinges väg 35, 11251 Stockholm, Sweden. ${ }^{3}$ Eisai, Inc, 100 Tice Boulevard, Woodcliff Lake, NJ 07677, USA.

Published: 24 Mar 2014 


\section{References}

1. Wimo A, Prince M: World Alzheimer Report 2010: The Global Economic Impact of Dementia. London, UK: Alzheimer's Disease International; 2010.

2. Glenner GG, Wong CW: Alzheimer's disease and down syndrome: sharing of a unique cerebrovascular amyloid fibril protein. Biochem Biophys Res Commun 1984, 122:1131-1135.

3. Hardy J, Selkoe DJ: The amyloid hypothesis of Alzheimer's disease: progress and problems on the road to therapeutics. Science 2002, 297:353-356.

4. Golde T: The $A \beta$ hypothesis: leading us to rationally-designed therapeutic strategies for the treatment or prevention of Alzheimer disease. Brain Pathol 2005, 15:84-87.

5. Chartier-Harlin M-C, Crawford F, Houlden H: Early-onset Alzheimer's disease caused by mutations at codon 717 of the $\beta$-amyloid precursor protein gene. Nature 1991, 353:844-846.

6. Mullan M, Crawford F, Axelman K, Houlden H, Lilius L, Winblad B, Lannfelt L: A pathogenic mutation for probable Alzheimer's disease in the APP gene at the N-terminus of $\beta$-amyloid. Nat Genet 1992, 1:345-347.

7. Citron M, Oltersdorf T, Haass C, McConlogue L, Hung A, Seubert P, VigoPelfrey C, Lieberburg I, Selkoe DJ: Mutation of the $\beta$-amyloid precursor protein in familial Alzheimer's disease increases $\beta$-protein production. Nature 1992, 360:672-674.

8. Nilsberth C, Westlind-Danielsson A, Eckman CB, Condron MM, Axelman K Forsell C, Stenh C, Luthman J, Teplow DB, Younkin SG, Näslund J, Lannfelt L: The 'Arctic' APP mutation (E693G) causes Alzheimer's disease by enhanced A $\beta$ protofibril formation. Nat Neurosci 2001, 4:887-893.

9. Scheuner D, Eckman CB, Jensen M, Song X, Citron M, Suzuki N, Bird TD, Hardy J, Hutton M, Kukull W, Larson E, Levy-Lahad E, Viitanen M, Peskind E, Poorkaj P, Schellenberg G, Tanzi RE, Wasco W, Lannfelt L, Selkoe DJ, Younkin SG: Secreted amyloid $\beta$-protein similar to that in senile plaques of Alzheimer's disease is increased in vivo by the presenilin 1 and 2 and APP mutations linked to familial Alzheimer's disease. Nat Med 1996, 2:864-870,

10. Brouwers N, Sleegers K, Van Broeckhoven C: Molecular genetics of Alzheimer's disease: an update. Ann Med 2008, 40:562-583.

11. Schöll $M$, Wall $A$, Thordardottir $S$, Ferreira $D$, Bogdanovic $N$, Långström $B$, Almkvist O, Graff C, Nordberg A: Low PiB PET retention in presence of pathologic CSF biomarkers in Arctic APP mutation carriers. Neurology 2012, 79:229-236

12. Mawuenyega KG, Sigurdson W, Ovod V, Munsell L, Kasten T, Morris JC, Yarasheski KE, Bateman RJ: Decreased clearance of CNS $\beta$-amyloid in Alzheimer's disease. Science 2010, 330:1774.

13. Jonsson T, Atwal JK, Steinberg S, Snaedal J, Jonsson PV, Bjornsson S, Stefansson H, Sulem P, Gudbjartsson D, Maloney J, Hovte K, Gustafson A, Liu Y, Bhangale T, Graham RR, Huttenlocher J, Bjornsdottir G, Andreassen OA, Jönsson EG, Palotie A, Behrens TW, Magnusson OT, Kong A, Thorsteinsdottir $U$, Watts RJ, Stefansson K: A mutation in APP protects against Alzheimer's disease and age-related cognitive decline. Nature 2012, 488:96-99.

14. Barten D, Meredith JJ, Zaczek R, Houston J, Albright C: Gamma-secretase inhibitors for Alzheimer's disease: balancing efficacy and toxicity. Drugs $R$ D 2006, 7:87-97.

15. Doody RS, Raman R, Farlow M, Iwatsubo T, Vellas B, Joffe S, Kieburtz K, He F, Sun X, Thomas RG, Aisen PS, Sethuraman G, Mohs R: A phase 3 trial of semagacestat for treatment of Alzheimer's disease. N Engl J Med 2013, 369:341-350.

16. Martenyi F, Dean R, Lowe $S$, Nakano M, Monk S, Willis B, Gonzales $C$, Mergott D: BACE inhibitor LY2886721 safety and central and peripheral PK and PD in healthy subjects (HSs). Alzheimers Dement 2012, 8:P583P584.

17. Forman M, Palcza J, Tseng J, Leempoels J, Ramael S, Han D, Jhee S, Ereshefsky L, Tanen M, Laterza O, Dockendorf M, Krishna G, MA L, Wagner J, Troyer M: The novel BACE inhibitor MK-8931 dramatically lowers cerebrospinal fluid peptides in healthy subjects following single-and multiple dose administration. Alzheimers Dement 2012, 8:P704.

18. Jeppsson F, Eketjäll S, Janson J, Karlström S, Gustavsson S, Olsson LL, Radesäter AC, Ploeger B, Cebers G, Kolmodin K, Swahn BM, von Berg S, Bueters T, Fälting J: Discovery of AZD3839, a potent and selective BACE1 inhibitor clinical candidate for the treatment of Alzheimer's disease. J Biochem 2012, 287:41245-41257.

19. Gunn AP, Masters $C L$, Cherny RA: Pyroglutamate-A $\beta$ : role in the natural history of Alzheimer's disease. Int J Biochem Cell Biol 2010, 42:1915-1918
20. Salloway $S$, Sperling R, Keren R, Porsteinsson AP, van Dyck CH, Tariot PN, Gilman S, Arnold D, Abushakra S, Hernandez C, Crans G, Liang E, Quinn G, Bairu M, Pastrak A, Cedarbaum JM, ELND005-AD201 Investigators: A phase 2 randomized trial of ELND005, scyllo-inositol, in mild to moderate Alzheimer disease. Neurology 2011, 77:1253-1262.

21. Aisen PS, Gauthier S, Ferris SH, Saumier D, Haine D, Garceau D, Duong A Suhy J, Oh J, Lau WC, Sampalis J: Tramiprosate in mild-to-moderate Alzheimer's disease - a randomized, double-blind, placebo-controlled, multicentre study (the Alphase study). Arch Med Sci 2011, 7:102-111.

22. Gilman S, Koller M, Black R, Jenkins L, Griffith S, Fox N, Eisner L, Kirby L, Rovira M, Forette F, Orgogozo J: Clinical effects of $A \beta$ immunization (AN1792) in patients with AD in an interrupted trial. Neurology 2005, 64:1553-1562

23. Salloway S, Sperling R, Fox NC, Blennow K, Klunk W, Raskind M, Sabbagh M, Honig LS, Porsteinsson AP, Ferris S, Reichert M, Ketter N, Nejadnik B, Guenzler V, Miloslavsky M, Wang D, Lu Y, Lull J, Tudor IC, Liu E, Grundman M, Yuen E, Black R, Brashear HR, Bapineuzumab 301 and 302 Clinical Trial Investigators: Two phase 3 trials of bapineuzumab in mild-to-moderate Alzheimer's disease. N Engl J Med 2014, 370:322-333.

24. Nicoll JA, Wilkinson D, Holmes C, Steart P, Markham H, Weller RO: Neuropathology of human Alzheimer disease after immunization with amyloid- $\beta$ peptide: a case report. Nat Med 2003, 9:448-452.

25. Vellas B, Black R, Thal LJ, Fox NC, Daniels M, McLennan G, Tompkins C, Leibman C, Pomfret M, Grundman M: Long-term follow-up of patients immunized with AN1792: reduced functional decline in antibody responders. Curr Alzheimer Res 2009, 6:144-151.

26. Blennow K, Zetterberg H, Rinne J, Salloway S, Wei J, Black R, Grundman M, Liu E: Effect of immunotherapy with bapineuzumab on cerebrospinal fluid biomarker levels in patients with mild to moderate Alzheimer disease. Arch Neurol 2012, 69:1002-1010.

27. Rinne J, Brooks D, Rossor M, Fox N, Bullock R, Klunk W, Mathis C, Blennow K, Barakos J, Okello A, Rodriguez Martinez De Liano S, Liu E, Koller M, Gregg K, Schenk D, Black R, Grundman M: 11C-PiB PET assessment of change in fibrillar amyloid- $\beta$ load in patients with Alzheimer's disease treated with bapineuzumab: a phase 2 , double-blind, placebo-controlled, ascending dose study. Lancet Neurol 2010, 9:363-372.

28. Farlow M, Arnold SE, van Dyck CH, Aisen PS, Snider BJ, Porsteinsson AP, Friedrich S, Dean RA, Gonzales C, Sethuraman G, DeMattos RB, Mohs R, Raul SM, Siemers ER: Safety and biomarker effects of solanezumab in patients with Alzheimer's disease. Alzheimers Dement 2012, 8:261-271.

29. Eli L: Lilly announces detailed results of the phase 3 solanezumab EXPEDITION studies following a presentation of the independent analyses by the Alzheimer's disease Cooperative Study (ADCS). Indianapolis, IN: Lilly; 2012. https://investor. lilly.com/releasedetail.cfm?releaseid=711933.

30. Winblad B, Andreasen N, Minthon L, Floesser A, Imbert G, Dumortier T, Maguire RP, Blennow K, Lundmark J, Staufenbiel M, Orgogozo JM, Graf A: Safety, tolerability and antibody response of active $A \beta$ immunotherapy with CAD106 in patients with Alzheimer's disease. Randomised, doubleblind, placebo-controlled, first-in-human study. Lancet 2012, 11:597-604.

31. Katzman R: Alzheimer's disease. N Engl J Med 1986, 314:964-973.

32. Terry RD, Masliah E, Salmon DP, Butters N, DeTeresa R, Hill R, Hansen LA, Katzman R: Physical basis of cognitive alterations in Alzheimer's disease: synapse loss is the major correlate of cognitive impairment. Ann Neurol 1991, 30:572-580.

33. Dickson DW, Chrystal HA, Bevona C, Honer W, Vincent I, Davies P. Correlations of synaptic and pathological markers with cognition of the elderly. Neurobiol Aging 1995, 16:285-298.

34. Näslund J, Haroutunian V, Mohs R, Davis KL, Davies P, Greengard P, Buxbaum J: Correlation between elevated levels of amyloid $\beta$-peptide in the brain and cognitive decline. JAMA 2000, 283:1571-1577.

35. Busciglio J, Lorenzo A, Yankner B: Methological variables in the assessment of $\beta$-amyloid neurotoxicity. Neurobiol Aging 1992, 13:609-612.

36. Pike $C J$, Walancewics AJ, Glabe CG, Cotman CW: In vitro aging of $\beta$ amyloid protein causes peptide aggregation and neurotoxicity. Brain Res 1991, 563:311-314

37. Walsh DM, Lomakin A, Benedek GB, Condron MM, Teplow DB: Amyloid $\beta$ protein fibrillogenesis. J Biol Chem 1997, 272:22364-22372.

38. Hartley DM, Walsh DM, Ye CP, Diehl T, Vasquez S, Vassilev PM, Teplow DB, Selkoe DJ: Protofibrillar intermediates of amyloid $\beta$-protein induce acute electrophysiological changes and progressive neurotoxicity in cortical neurons. J Neurosci 1999, 19:8876-8884. 
39. O'Nuallain B, Freir DB, Nicoll AJ, Risse E, Ferguson N, Herron CE, Collinge J, Walsh DM: Amyloid $\beta$-protein dimers rapidly form stable synaptotoxic protofibrils. J Neurosci 2010, 30:14411-14419.

40. Paranjape GS, Gouwens LK, Osborn DC, Nichols MR: Isolated amyloid- $\beta$ (1-42) protofibrils, but not isolated fibrils, are robust stimulators of microglia. ACS Chem Neurosci 2012, 3:302-311.

41. McLean C, Cherny R, Fraser F, Fuller S, Smith M, Beyreuther K, Bush A, Masters $C$ : Soluble pool of $A \beta$ amyloid as a determinant of severity of neurodegeneration in Alzheimer's disease. Ann Neurol 1999, 46:860-866.

42. Lesne S, Koh M, Kotilinek L, Kayed R, Glabe C, Yang A, Gallagher M, Ashe K: A specific amyloid- $\beta$ protein assembly in the brain impairs memory. Nature 2006, 440:352-357.

43. Englund $H$, Sehlin D, Johansson A-S, Nilsson LN, Gellerfors P, Paulie S, Lannfelt $L$, Ekholm Pettersson F: Sensitive ELISA detection of amyloid- $\beta$ protofibrils in biological samples. J Neurochem 2007, 103:334-345.

44. Sehlin D, Englund $H$, Simu B, Karlsson M, Ingelsson M, Nikolajeff F, Lannfelt $L$, Ekholm Pettersson F: Large aggregates are the major soluble $A \beta$ species in $A D$ brain fractionated with density gradient ultracentrifugation. PLoS One 2012, 7:e32014.

45. Johansson A-S, Berglind Dehlin F, Karlsson G, Edwards K, Gellerfors P, Lannfelt $L$ : Physiochemical characterization of the Alzheimer's disease-related peptides A 1-42Arctic and AB1-42wt. FEBS J 2006, 273:2618-2630.

46. Sahlin C, Lord A, Magnusson K, Englund H, Almeida CG, Greengard P, Nyberg F, Gouras GK, Lannfelt L, Nilsson LN: The Arctic Alzheimer mutation favors intracellular amyloid- $\beta$ production by making amyloid precursor protein less available to alpha-secretase. J Neurochem 2007, 101:854-862.

47. Lord A, Kalimo H, Eckman CB, Zhang X-Q, Lannfelt L, Nilsson LN: The Arctic Alzheimer mutation facilitates early intraneuronal $A \beta$ aggregation and senile plaque formation in transgenic mice. Neurobiol Aging 2006, 27:6777.

48. Knobloch M, Konietzko U, Krebs DC, Nitsch RM: Intracellular A $\beta$ and cognitive deficits precede $\beta$-amyloid deposition in transgenic $\operatorname{arc} A \beta$ mice. Neurobiol Aging 2007, 28:1297-1306.

49. Lord A, Englund H, Söderberg L, Tucker S, Clausen F, Hillered L, Gordon M, Morgan D, Lannfelt L, Ekholm Pettersson F, Nilsson LN: Amyloid- $\beta$ protofibril levels correlate with spatial learning in Arctic Alzheimer's disease transgenic mice. FEBS J 2009, 276:995-1006.

50. Lord A, Gumucio A, Englund H, Sehlin D, Screpanti Sundquist V, Söderberg L, Möller C, Gellerfors P, Lannfelt L, Ekholm Pettersson F, Nilsson LN: An amyloid- $\beta$ protofibril-selective antibody prevents amyloid formation in a mouse model of Alzheimer's disease. Neurobiol Dis 2009, 36:425-434.

51. Jack CRJ, Knopman DS, Jagust WJ, Petersen RC, Weiner MW, Aisen PS, Shaw LM, Vemuri P, Wiste HJ, Weigland SD, Lesnick TG, Pankratz VS, Donohue MC, Trojanowski JQ: Tracking pathophysiological processes in Alzheimer's disease: an updated hypothetical model of dynamic biomarkers. Lancet Neurol 2013, 12:207-216.

52. Blennow K, Zetterberg $\mathrm{H}$ : The application of cerebrospinal fluid biomarkers in early diagnosis of Alzheimer disease. Med Clin North Am 2013, 97:369-376.

53. Mitchell AJ, Shiri-Feshki M: Rate of progression of mild cognitive impairment to dementia - meta-analysis of 41 robust inception-cohort studies. Acta Psychiatr Scand 2009, 119:252-265.

54. CTAD: CTAD: New Data on Sola, Bapi, Spark Theragnostics Debate. In New Data on Sola, Bapi, Spark Theragnostics Debate. http://www.alzforum. org/news/conference-coverage/ctad-new-data-sola-bapi-sparktheragnostics-debate.

55. Okello A, Koivunen J, Edison P, Archer HA, Turkheimer FE, Någren K, Bullock R, Walker Z, Kennedy A, Fox NC, Rossor MN, Rinne JO, Brooks DJ: Conversion of amyloid positive and negative $\mathrm{MCI}$ to $\mathrm{AD}$ over 3 years: an 11C-PIB PET study. Neurology 2009, 73:754-760.

56. Logovinsky V, Hendrix S, Perdomo C, Wang J, Satlin A: New composite score demonstrates sensitivity to disease progression and treatment effects. Florence, Italy: Paper presented at the 11th International Conference on Alzheimer's and Parkinson's Disease (AD/PD); 2013.

57. Logovinsky V: New Frontier: developing outcome measures for pre-dementia trials. http://www.alzforum.org/webinars/new-frontier-developing-outcomemeasures-pre-dementia-trials.
58. Jack CR, Knopman DS, Jagust WJ, Shaw LM, Aisen PS, Weiner MW, Petersen RC, Trojanowski JQ: Hypothetical model of dynamic biomarkers of the Alzheimer's pathological cascade. Lancet Neurol 2010, 9:119-128.

59. Satlin A, Logovinsky V, Wang J, Swanson C, Berry S, Berry D: Bayesian adaptive trial design: a new approach for phase 2 clinical trials in Alzheimer's disease. Monte Carlo, Monaco: Paper presented at Clinical Trials in Alzheimer's Disease (CTAD); 2012.

\subsection{6/alzrt246}

Cite this article as: Lannfelt et al:: Perspectives on future Alzheimer therapies: amyloid- $\beta$ protofibrils - a new target for immunotherapy with BAN2401 in Alzheimer's disease. Alzheimer's Research \& Therapy 2014, 6:16 